VISUAL SPACES OF CHANGE: DESIGNING INTERIORITY

SHELTER, SHAPE, PLACE, ATMOSPHERE

ISSN: 2183-8976 [PRINT] 2183-9468 [ONLINE]

Volume 5, Issue 1 | Publication year: 2020

DOI 10.24840/2183-8976_2020-0005_0001_4

(C) SCOPIO EDITIONS

HOMEPAGE: HTTPS://WWW.SOPHIAJOURNAL.NET

\title{
THE ROLE OF ARCHITECTURE IN AN ENGAGING AND MEANINGFUL EXPERIENCE OF THE PHYSICAL EXHIBITION
}

\author{
Bárbara Coutinho and Ana Tostões
}

\begin{abstract}
While recognising the part that digital media play in bringing about greater accessibility to artworks display and ensuring that they are more visible, this paper argues that the physical exhibition continues to be the primary place for the public to encounter the arts, as it can offer an engaging and meaningful aesthetic experience through which people can transcend their own existence. As such, it is essential to rethink now, in the scope of an increasing digital world, the exhibition in conceptual and methodological terms. For this purpose, the exhibition space must be considered as content rather than container and the exhibition as a work, often with the intentionality of a "total work of art", rather than just a vehicle for exhibiting artworks and objects. With this purpose in mind, this paper proposes a re-reading of the exhibition designs of Frederick Kiesler (1890-1965), Franco Albini (1905-1977) and Lina Bo Bardi (1914-1992) in order to evaluate how their theory and practice can provide useful lessons for our contemporary thinking. The three architects, assuming the role of curators, use only the specific language of an exhibition and remix conventional modes of communication and architectural vocabulary, exploring the natural and artificial light, materials, layouts, surfaces and geometries in innovative ways. They considered the exhibition to be a work of art, overcoming the container/content dichotomy and trigging an intersubjective and self-reflective participation. Kiesler, Albini and Bo Bardi may all be considered visionaries of our time, as they offer a landscape that stimulates our curiosity through a multiplicity of information arranged in a multisensory way, allowing each visitor to discover associations between himself and his surroundings. None of them simply created an opportunity for distraction or entertainment. This perspective is all the more pertinent nowadays, as the processes of digitalising information and virtualising the real may well lead to the dematerialization of the physical experience of art. By drawing upon these historical examples, this paper seeks to contribute to current study on how an exhibition can stimulate the cognitive, emotional and spiritual intelligence of each visitor and clarify the importance of this effect in 21st century museums and society at large.
\end{abstract}

Keywords: Curatorship; Exhibition Space; Installation; Architecture; Museography 
Bárbara Coutinho is an Art historian. She has a degree in History of Art, a Master's degree in Contemporary Art History, Post-graduate degree in Art History Education and holds a PhD on Culture and Technology in Architecture with the thesis "The Exhibition Space as a "Total Work of Art' - The Museum of the 21st century, a place for a global aesthetic experience". Director and programmer of MUDE - Museu do Design e da Moda, Colecção Francisco Capelo since 2006, she is the author of the museum museological programme. As a Guest Assistant Professor at Técnico, University of Lisbon, she teaches Architecture Theory and History. Her work is divided between research, teaching, curatorship and writing, having as main topics of interest museology and curating, architecture and exhibition space, design and contemporary creation. Among the several exhibitions she curated, particular relevance for the traveling exhibition How do we pronounce design in portuguese? (2014-2020).

Ana Tostões is an architect, architectural critic and historian, president of Docomomo International and editor of the Docomomo Journal. She is a Full Professor at Técnico, University of Lisbon, where she is in charge of the Architectural Scientific Field. She has a degree in Architecture, a Master's degree in History of Art with a thesis entitled Os Verdes Anos na Arquitectura Portuguesa dos Anos 50, and holds a PhD on Culture and Technology in Modern Architecture awarded with the $\mathrm{X}$ Bienal Ibero-Americana de Arquitectura y Urbanismo Prize 2016. She has been invited professor at universities worldwide. Her research field is the Critical History and Theory of Contemporary Architecture, focusing on the relationship between European, Asian, African and American cultures. She coordinated the research project "Exchanging World Visions which publication Modern Architecture in Africa: Angola and Mozambique" was awarded with the Gulbenkian Prize 2014, and currently coordinates the research project "Cure and Care the rehabilitation". 


\section{Rediscovering the meaning of the "here and now"}

We live times of profound challenges and possibilities for curatorial practice. Digital transformation is enabling improved conservation and study of artworks, while virtual museums and exhibitions are able to disseminate their images globally, democratising art. However, the resulting disconnect from the surrounding physical environment and the dematerialisation of the experience of art can contribute to what Pallasmaa calls "the tactile and sensorial desensitisation of man"1, reducing the vital importance of the arts to the overall development of humankind. Consequently, it is crucial to rethink the physical exhibition, and to do so with sensitivity and responsibility.

Over the last three decades, in the wake of abundant academic work on the architecture of museums, the exhibition itself became the focus of scrutiny. Numerous conferences and discussions on this subject took place and several books were published with the purpose of documenting the exhibitions that made art history. The historiography of modern and contemporary art exhibitions saw significant advancement with the work of Bruce Altshuler, Victoria Newhouse and Hans Ulrich Obrist. In the field of theory on the exhibition as a medium, the published titles of Elena Filipovic, Kali Tzortzi, Melanie Townsend, M.C.K. Lam and James Putnam deserve special mention. The number of historical exhibitions that have been replicated or revisited since the beginning of the 21st century also show how the exhibition has gained in stature. Greenberg states that this trend has given rise to a specific genre of exhibitions - the "remembering exhibitions".2 As Greenberg sees it, this type of exhibition can take three forms: a re-creation of the original exhibition, with the works displayed or replicas arranged according to the same discourse and location; reference to a previous incarnation, with a reinterpretation of its title or subject; and the presentation and publication, whether in a physical or digital format, of material that documents the creative process behind an exhibition. There are a number of examples of revisited exhibitions. In 2013, Fondazione Prada presented the exhibition When Attitudes Become Form: Bern 1969/Venice 2013. Rem Koolhaas designed the space that rebuilt the historical exhibition When Attitudes Become Form, curated by Harald Szeemann in 1969, within the Palacio Ca' Corner della Regina; one year later, the Jewish Museum presented the exhibition Other Primary Structures, curated by Jens Hoffmann, which revisited the seminal exhibition of 1966, Primary Structures: Younger American and British Sculpture, curated by Kynaston McShine; in 2019-2020 the Calouste Gulbenkian Foundation in Lisbon presented the exhibition Art on Display. Ways to exhibit 1949-1969, which recreated various exhibition designs to provide points of comparison with the display solution used for the opening of the museum in 1969.

1Pallasmaa, Juhani. The eyes of the skin: architecture and the senses. New Jersey: John Wiley \& Sons, 2005 [1996]. 2 Greenberg, Reesa. "'Remembering Exhibitions': From Point to Line to Web", Tate Papers, n.12, Autumn 2009. DOI: http://www.tate.org.uk/research/publications/tate-papers/12/remembering-exhibitions-from-point-to-line-to-web (Accessed: 5 may 2016). 
As early as 1935, Walter Benjamin noted the enormous value of art exhibitions and their immense potential for having an impact with the public, defining this quality as "exhibitability" or "exhibition value3. Today, the originality, uniqueness and authenticity of the encounter come more from the experience lived by each viewer rather than the artwork itself; in other words, "the aura of artworks has shifted towards their public"4. The reason for visiting an exhibition is no longer, therefore, so much a desire to see a specific artwork (which is often accessible to a higher level of quality via various digital means), but rather the presence of the self in a particular special place. In this case, the design of the exhibition space takes on greater importance, and it is essential that each museum rethink its exhibitions, their themes, any curatorial speeches and the scenography in order to trigger intersubjective and self-reflective participation on the part of its visitors. As Buergel and Noack state, "The experience of art is always the experience of life. If we wish to redefine this relationship, we require a medium to remove us from our immediate 'living context'. The aesthetic experience, which begins where meaning in the conventional sense ends, could be such a medium"5. The exhibition can thus offer that unique and unifying aesthetic experience between the self, the other and the world through art, expanding our empathy, sensitivity and critical thinking. In the process, it restores the ancestral place of art in the life of man, amplifying the relational value of culture, while reinforcing the museum's civic role as a place conducive to reforging attitudes, values, emotions and capabilities.

Given that the organisation of space is the very essence of architecture, as Zevi asserts ${ }^{6}$, and that an exhibition embodies the interrelationship between the place, the exhibit display system and the placement of objects, the phenomenological angle to architecture is particularly important, as it puts the viewer's own perception centre-stage ${ }^{7}$. The primacy given to the point of view of the subject can allow a better understanding of the physical dimension of the aesthetic experience and, therefore, lead to the creation of open, challenging correlations between the pieces, the space and the public. Frederick Kiesler, Franco Albini and Lina Bo Bardi were selected as case studies due all evinced such an approach, as they clearly considered the multisensory experience of space and the intellectual, emotional and spiritual dimension of man when designing their exhibitions. As such, this paper intends to analyse their exhibition designs with a view to evaluating whether they were able to activate the space as content, without silencing the pieces on display or becoming a mere moment of distraction and entertainment.

3Benjamin, Walter in Steeds, Lucy (ed.) Exhibition. Documents of Contemporary Art. London/Cambridge, Massachusetts: Whitechapel Gallery/The MIT Press, 2014, p.26.

4 Bourriaud, Nicolas. Relational Aesthetics. Dijon: Les Presses du Réel. 2002, p.58.

5 Buergel, Roger; Noack, Ruth. "Documenta 12 - 100 days of art in Kassel". (2007) Available in: http://www.documenta12. de/index.php?id=aussttelung\&L=1 (Accessed: 2 September 2016).

6 Zevi, Bruno. Saber Ver a Arquitetura. Lisbon: Editora Arcádia, 1966 [1948].

7 Pallasmaa, Juhani. The eyes of the skin: architecture and the senses. New Jersey: John Wiley \& Sons, 2005 [1996]. 


\section{The exhibition as a galaxy}

Frederick Kiesler devised and develops radical exhibition experiences throughout his life. Architect, sculptor, designer, artist, poet and theorist, Kiesler did not complete his studies in architecture or arts, but by the early 1920s he was already working as a set designer. This experience proved important to his later development of the theory of correlationism in exhibition design, and shaped his visionary ideas. Kiesler saw the exhibition as a galaxy inhabited by objects, spaces and visitors, a place where the arts were reunited, reasserting themselves as a vital force for human beings. In 1942, Kiesler summed up the guiding idea behind all of his exhibition work in a brief but enlightening excerpt: "Primitive man knew no separate worlds of vision and of fact. He knew one world in which both were continually present within the pattern of everyday experience. And when he carved and painted the walls of his cave or the side of a cliff, no frames or borders cut off his works of art from space or life - the same space, the same life that flowed around his animals, his demons and himself." scope, insofar as it conceives of the exhibition space as a complex system of multiple entities or particles that generate their own energy fields. It is, in itself, a totality that cannot be fully embraced, but of which man is a part, like a small grain or particle. In the exhibition as a galaxy, all the elements have the same importance and exist in a dynamic intercorrelation, creating an environment that invites us to experience it in a mystical sense. Each element is developed to the extent that it establishes intercorrelations with the remaining elements of the "unity" of time-space-architecture, whose main characteristic is the plasticity and elasticity of each of its components. At the genesis of Kiesler's correlational theory lies the conviction that the essence of reality is not found in each "thing" itself, but in its correlation with its environment, proffering a holistic understanding of humankind and the universe. As such, we can understand correlationism to be a science of relations. As Kiesler puts it, "The traditional art object, be it a painting, a sculpture or a piece of architecture, is no longer seen as an isolated entity but must be considered within the context of this expanding environment. The environment becomes equally important as the object, if not more so, because the object breathes into its surroundings but also inhales the realities of the environment, no matter what the space."'

8 Kiesler, Frederick, Manifeste du Corréalisme, 1947. Fac-símile in Bogner, Dieter; Noever, Peter. (ed.) Frederick J. Kiesler. Endless Space. Vienna: MAK and Hatje Cantz Publishers, 2001, p.174.

9 Kiesler, Frederick, "Note on Designing the Gallery and Press Release Pertaining to the Architectural Aspects of the Gallery" (1942) in Davidson, Susan; Rylands, Philip et al. (ed.) Peggy Guggenheim \& Frederick Kiesler: The Story of Art of this Century. New York: Guggenheim Museum Publications, 2004, p.42. 
Although the Manifesto of Correalism was written in 1947 and published in 1949, its ideas began to be experienced many years before in the Internationale Ausstellung neuer Theatertechnik (Vienna, 1924) and the Austrian pavilion Raumstadt (Paris, 1925). In 1924, Kiesler developed a modular structure that allowed the placement of two-dimensional and three-dimensional pieces on different planes, guaranteeing visual permeability between the various sites within the space ${ }^{10}$. The following year, within a darkened environment, Kiesler suspended from the ceiling a three-dimensional wooden structure created by the intersection of planes in different directions and heights, painted red, yellow and blue, with directed lighting. This brought a threedimensional aspect to the quest for neoplasticism research and allowed it to be physically experienced by the public as they walked through it ${ }^{11}$. However, it was only in 1942 that Kiesler fully manifested a correlational exhibition space, in the Art of this Century exhibition designed for the presentation of Peggy Guggenheim's collection of abstract and surrealist Art. Kiesler created different atmospheres that mirror each artistic project, presented within four different environments. Of note were two major measures that sought a reunion between space, art and man: the paintings were removed from conventional frames and displayed directly in space; and the visitor's perception was stimulated by his physical positioning within the room. According to Kiesler, the intention behind the first measure was to stop painting being artificially highlighted or a mere decorative element, but instead to make it an integral part of the room, establishing itself as an independent unit, but one that existed in a dynamic relationship with the space and the visitor ${ }^{12}$. The second gesture sought to trigger the visitor's perception through a series of correlational pieces that adjusted the usual positioning of the body in relation to space and objects. Kiesler thus devised a set of multifunctional elements in biomorphic shapes that worked as seating, allowing the visitor to sit and recline, or as a display system, allowing the public to orientate the pieces according to the best viewing angle ${ }^{13}$. [Fig.1].

10 Bogner, Dieter. "Staging Works of Art. Frederick Kiesler's Exhibition Design 1924-1957" in Susan; Rylands, Philip; et.al (ed.). Peggy Guggenheim \& Frederick Kiesler: The Story of Art of this Century. New York: Guggenheim Museum Publications, 2004. pp. 34-49.

11 lbid.

12 lbid.

13 Davidson, Susan; Rylands, Philip et al. (ed.) Peggy Guggenheim \& Frederick Kiesler: The Story of Art of this Century. New York: Guggenheim Museum Publications, 2004, pp.244-249. 


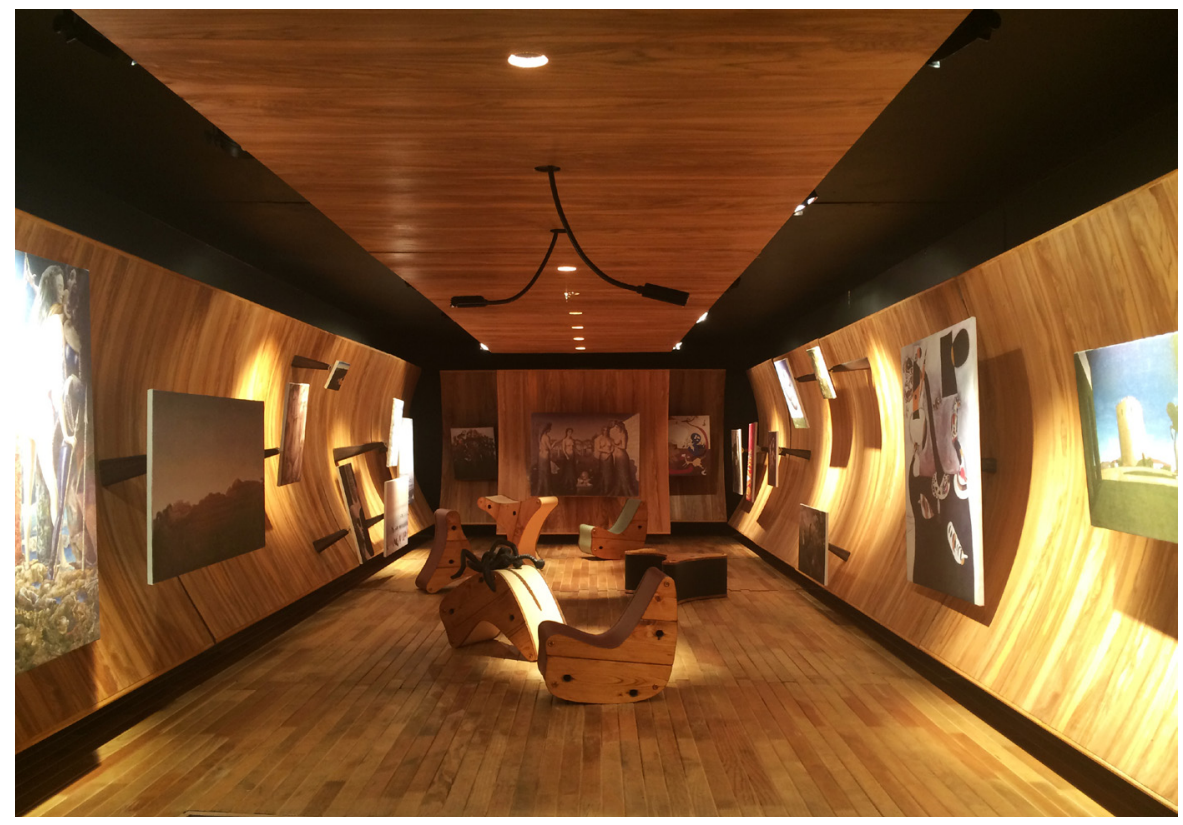

[Fig.1]

1:3 model of the Surrealist Gallery's show Art of this Century, displayed in the exhibition Frederick Kiesler: Life Visions, MAK, Vienna, 2016, ๑ the authors 


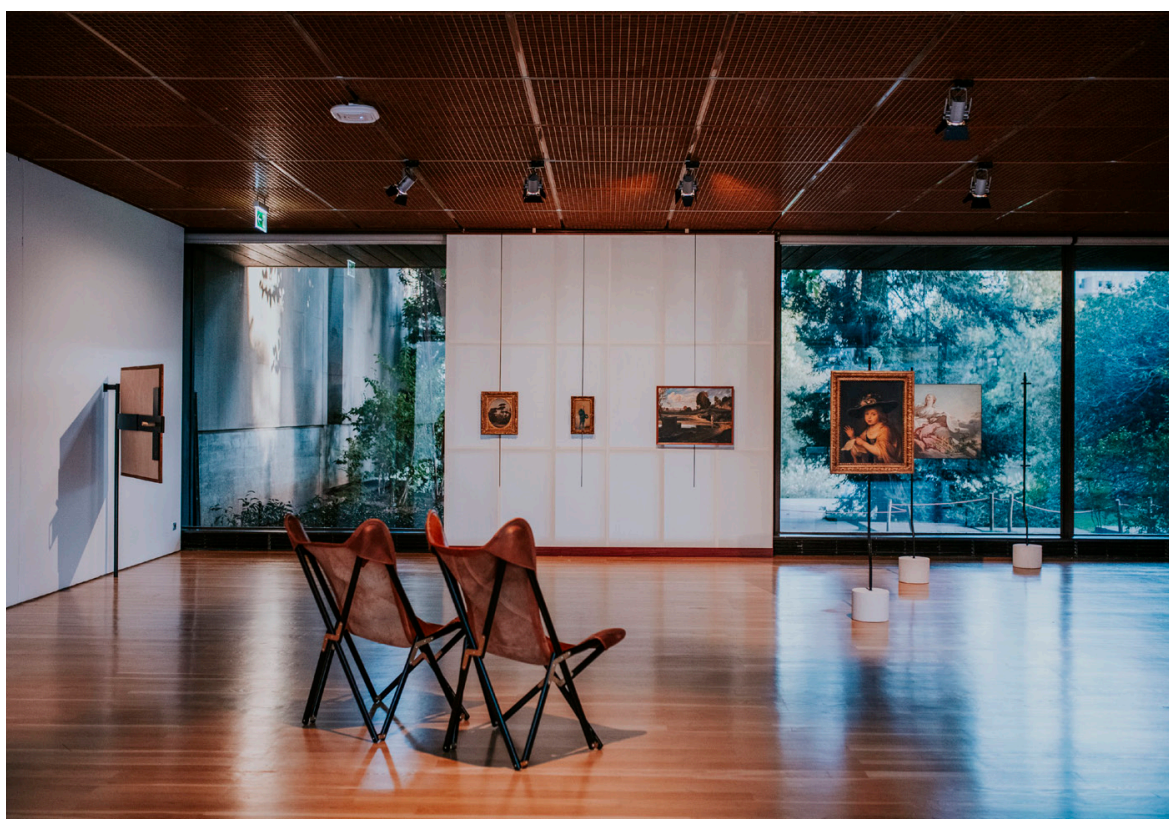

[Fig.2]

View of the exhibition Art on Display / Formas de expor 1949-69, with a replica of projects by Franco Albini and Franca Helg, Lisbon, Museu Calouste Gulbenkian, 2019. ( Pedro Pina - Museu Calouste Gulbenkian. 
The Exposition Internationale du Surrealism at the Galerie Maeght (Paris, 1947) is worth highlighting especially for its "Salle de Superstition", which Kiesler devised as a living organism, without any distinction between the pieces and the space ${ }^{14}$. Kiesler invited Marcel Duchamp, Max Ernst, Roberto Matta, Joan Miró and Yves Tanguy to collaborate on his work and steered their individual contributions. In this instance, Kiesler was not only the architect-curator of the exhibition, but also the artist who determined how other artists participated in his work. In this guise, as he relates ${ }^{15}$, he assumed the demiurge role of a new galaxy where all of the elements are in correlation.

Kiesler's drawings and sketches include visionary projects incorporating physical elements, through which he aspired to be able to offer the public the sensation of zero gravity in space. He believed that weightlessness would engender ways of contemplating the pieces and experiencing the space ${ }^{16}$. Although these designs were never actually executed, they give us an insight into Kiesler's belief that it was possible to change the way in which we perceive, feel and experience art.

\section{The exhibition as a relational place}

Franco Albini designed exhibitions over four decades and was a fixture at the Triennale di Milano for a number of years. Albini's stores designs, shop window displays and work on several exhibitions relating to Italian fascism over the period between the two world wars are particularly worthy of note. This experience gave him a heightened awareness of the power of advertising and the triggering effect of spaces, knowledge that he would later bring to bear on art exhibitions and museography after World War II.

The Scipione \& Black and White exhibition that Albini designed for the Pinacoteca di Brera in 1941 is particularly significant, as it attested to the characteristics that Albini would go on to explore in subsequent years, and which set him apart from other involved in Italian museography ${ }^{17}$. Albini ingeniously combined ancient and modern elements, displaying the historical artworks within a context informed by a contemporary sensibility. The utmost attention was given to every detail;

14 Kiesler, Frederick, Manifeste du Corréalisme, 1947. Facsimile in Bogner, Dieter; Noever, Peter. (ed.) Frederick J. Kiesler. Endless Space. Vienna: MAK and Hatje Cantz Publishers, 2001.

15 Bogner, Dieter. "Staging Works of Art. Frederick Kiesler's Exhibition Design 1924-1957" in Susan; Rylands, Philip; et.al (ed.). Peggy Guggenheim \& Frederick Kiesler: The Story of Art of this Century. New York: Guggenheim Museum Publications, 2004. p.47. 16 Bogner, Dieter. "Staging Works of Art. Frederick Kiesler's Exhibition Design 1924-1957" in Susan; Rylands, Philip; et.al (ed.). Peggy Guggenheim \& Frederick Kiesler: The Story of Art of this Century. New York: Guggenheim Museum Publications, 2004. pp. 34-49.

17 Franco Albini acted since 1958 as an important consultant for the Gulbenkian Foundation Museum and Headquaters project in Lisbon which confirms its notoriety in the field. See Tostões, Ana, Gulbenkian. The Buildings, Lisbon, FCG, 2016. 
all of the elements of the display system were meticulously crafted. An inventive solution was conceived for each artwork or object. Albini harnessed the emptiness (or air) of the room as an exhibition material, displaying the pieces on different planes in the open space ${ }^{18}$. The canvas was freed from the wall and placed within the room, on thin metal profiles that formed a grid of tensioned steel cables. This solution presented the paintings in a more object-like fashion, emphasising their three-dimensional nature and architectural quality, while allowing the visitor to appreciate their materiality ${ }^{19}$. Small apses in the brickwork, some 1.3 metres high, showcased certain artworks and offered a space for quiet contemplation, while the paper drawings were placed diagonally in aluminium and glass display cases. Spotlights suspended from tensioned steel cables or nestled within the profiles provided the lighting. Sets of old chairs were positioned next to some of the profiles, inviting visitors to stay for a while, chat or contemplate. These principles engaged the public and created a relational space. Albini created them in various locations, including the Palazzo Bianco in Genoa between 1949 and 1951, where he first worked with Franca Helg (1920-1989). One of several devices created by Albini and Helg is the famous Tripolina chair, which invites visitors to linger. Another is the poles embedded in bases, including one consisting of a slightly curved metal tube planted on an old head of a column - a Dada-inspired piece ${ }^{20}$. Special mention goes to the paintings with their frame removed, or those placed on lever arms to encourage viewer interaction. [Fig. 2]

18 Jenner, Ross. "Ambient atmospheres: exhibiting the immaterial in works by Italian rationalists Edoardo Persico and Franco Albini" in Löschke, S.K., Luscombe, D. (ed.), Interstices. Journal of architecture and related arts - 14 Immaterial Materialities Aspects of materiality and interactivity in art and architecture, 2013, pp. 13-24.

19 Anelli, Renato. "Gosto Moderno: O design da exposição e a exposição do design" in Latorraca, G. (ed). Maneiras de Expor: Arquitetura Expositiva de Lina Bo Bardi. São Paulo: Museu da Casa Brasileira, 2014, pp. 62-79.

20 Lanzarini, Orietta; Mulazzani, Marco. "L'esperienza del porgere: i musei di Franco Albini e Carlo Scarpa" in Bucci, F., Irace, F. (ed.) Zero Gravity. Franco Albini Construire le Modernità. Milan: Triennale Electa, 2006, pp. 149-163. 
The International Exhibition of Glass and Steel (Triennale di Milano, 1960), where Albini worked in collaboration with Jay Doblin (1920-1989), was remarkable as a perfect example of his precise positioning of artworks and design objects, activating the spatial qualities of the place by proposing inventive yet sophisticated installations that encouraged the visitor to undergo an experience in relation to his surroundings. Albini and Doblin made use of the different planes of a monumental staircase and the handrail structure to create a "light box" in which the glass and metal objects were placed, underlining the "architecture" of each piece and the structure of the place itself. The result is a continuous and dynamic line of light that underlines the movement of the staircase, transforming it into an architectural promenade through which the visitor may experience different perceptions of the surrounding space while contemplating the pieces "profiled" by the light, in contrast to the darkened environment, which seems almost to float within the space. This installation demonstrates how Albini uses the characteristics of the place to enhance the poetics of the exhibited object, showcasing it both formally and aesthetically. Albini thus considers the exhibition to be a relational space, arguing that "Architecture, which also shifts the focus of the work exhibited onto the public, now tends to 'set the public', if we can put it that way, rather than setting the work of art. Architecture creates a modern atmosphere around the visitor and for this reason it enters into a relationship with his sensibility, with his culture, with his mentality as a modern man." [Author's translation] ${ }^{21}$

Throughout his life's work, Albini developed a scenography that re-contextualised the historic artworks by bringing different times into dialogue, while activating the architectural heritage, considering it to be content in its own right, rather than simply a receptacle for content. To this end, he designed original display systems and conceived of the exhibition in a dramatic form. Through clear and unambiguous exhibition design, Albini brought a new dimension to the traditional relationship between the painting, frame and wall, teasing out the uniqueness of each piece and emphasising the volumes, plans and visual perspectives of the different elements. In this regard, his deep knowledge of the different materials, such as wood, metal, stone or concrete, and the masterful way in which he designed the manifold exhibition plinths and points of display brings a tactile quality to every detail. His deep appreciation for the sensorial quality of architecture and consummate attentiveness to the way in which visitors would experience the space through their senses are very much in evidence here. This reflects his awareness of the importance of introducing contemporary sensitivity to curatorship and exhibition design. Albini's exhibitions thus evince profound respect for the artefacts, a solid architectural grounding, special consideration for the visitor's perception and a refined visual sensibility.

21 Albini, Franco, 1954/55 in Bucci, Federico; Irace, Fulvio (ed) Zero Gravity. Franco Albini Construire le Modernità. Milan: Triennale Electa, 2006, p.72. 


\section{The exhibition as a celebration}

Lina Bo Bardi sought to re-establish an interconnection between life and arts for a political purpose. In accordance with the anti-museum concept of museology, Bo Bardi argued for the desecration of the arts and an anthropological perspective on culture. As a result, she fought for museums to welcome and disseminate all cultural expressions of daily life, thus serving as a truly democratic, participatory, meaningful and vital place. This perspective was behind Bo Bardi's militant conviction that culture and arts played a central role in the transformation of man and society. Committed to this idea both politically and socially. Bo Bardi believed that exhibitions must be experienced and felt by all the people ${ }^{22}$. One of the most striking features of her curatorial perspective was the way she was able to express both "erudite" and "popular" culture, working with tangible and intangible culture as a whole. As we named as "Comment réaliser la société industrielle au "paradis" ${ }^{\prime 23}$, Lina achieved everything that an architect's agenda might contain, without establishing any artistic or disciplinary limits. With her all-inclusive anthropological reading ${ }^{24,}$ she tackled the questions of the past and of history in the present in a pioneering manner, looking at the built heritage without any hierarchies. For her, monumental and erudite heritage and popular or industrial heritage were of equal value. Reaching beyond boundaries, she directed her attention to unorthodox themes as a way of surpassing the limits of art and architecture. In Salvador, she proposed the creation of a museum of popular art in the architectural complex of the Solar do Unhão, which she restored in an unorthodox manner in 1963. Lina projected an inspirational reuse of this building and, behaving as if it were a form of manifesto, she highlighted the contrast between the language of the original seventeenthcentury building and the identity of the internal space, stripping it of unnecessary frills and deliberately leaving it unfinished: "A museum that must have its own didactic approach in order

to be a "true" museum, a living museum, and not a museum in the most outmoded sense of the word." 25 [Fig.3]

\footnotetext{
22 Latorraca, Giancarlo (ed.) Maneiras de Expor: Arquitetura Expositiva de Lina Bo Bardi. São Paulo: Museu da Casa Brasileira, 2014, p.11.

23 Tostões, Ana, "Lina Bo Bardi, faire de la ville la citadelle de la libertè», Matières 16. Lausanne : EPFL Press, Laboratoire de théorie et histoire, Septembre 2020, p.67.

24 See Sérgio Buarque de Holanda, Raizes do Brasil, Lisbon: Gravida, 2000 [1936]; Sérgio Buarque de Holanda, Visão do Paraiso. Os Motivos Edênicos no Descobrimento e Colonização do Brasil, São Paulo: Brasiliense, Publifolha, 2000 [1959]; Gilberto Freyre, Casa Grande e Senzala, Lisbon: Livros do Brasil, 1957 [1933]; Caio Prado Júnior, Formação do Brasil Contemporâneo, São Paulo: Ed. Brasiliense, 1996 [1942]; Darcy Ribeiro, "Culturas e Linguas indigenas do Brasil", Separata de Educação e Ciências Sociais, ano Il, vol. 2, nº 6, p. 4-102, Rio de Janeiro, 1957.
}

25 Ibid, p.101. 


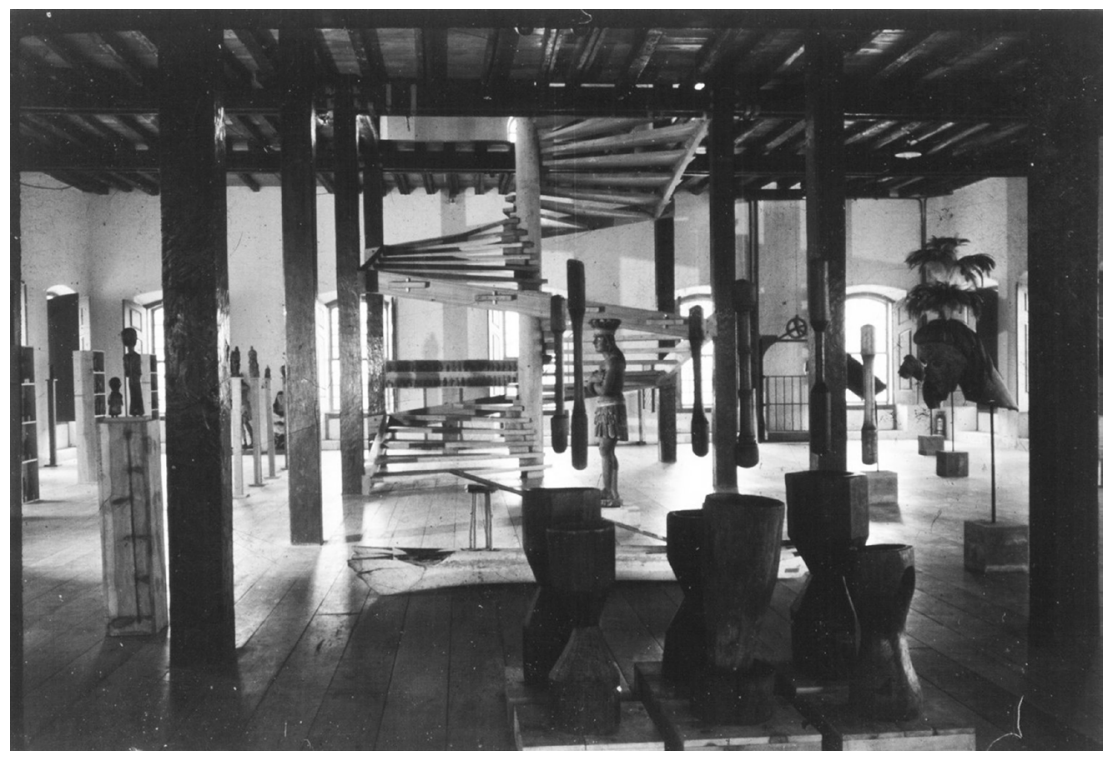

Every project that Bo Bardi undertook reveals her understanding of art as "a highly skilled piece of work" ${ }^{26}$ and a collective event, rather than an individual action without a broader context. The way in which Bo Bardi emphasis the universality of an artefact rather than its specific value is of particular interest. She did this by proposing juxtapositions and interrelationships between pieces of different types and periods or mixing ancient art with contemporary creations, archaeological remains, industrial products and crafts so as to question categories and stereotypes ${ }^{27}$. This deliberate curatorial approach was expressed by povera aesthetics and apparently simple language, but remained cheerful and unpretentious at the same time.

26 Bo Bardi, Lina (1970) Pedrosa, Adriano; Proença, Luiza (edit.) Concreto e Cristal: O acervo do MASP nos Cavaletes de Lina Bo Bardi. São Paulo: Cobogó e MASP, 2015, p.135.

27 Latorraca, Giancarlo (ed.) Maneiras de Expor: Arquitetura Expositiva de Lina Bo Bardi. São Paulo: Museu da Casa Brasileira, 2014, p.11. 
The emphasis on the expressiveness of poor materials, usually associated with the use of 
natural elements and ancient techniques, also had a political intention behind it, as it pointed to an alternative to consumerist society ${ }^{28}$. These views would prove particularly important in her architectural project Sesc Fábrica da Pompeia.

Bo Bardi always brought an atmosphere of a revelry, celebration and inclusiveness to the exhibition space ${ }^{29}$. This is visible in the incorporation of cooking, traditional dances, mysticism, sounds and popular references, such as the Brazilian terreiro de candoble [house in which the Candomblé religion is practiced] and the markets of the northeastern hinterland. In terms of spatial organisation, Bo Bardi chose a free and open space, exploring the notions of transparency, flexibility and multiple fields of vision, once again with an aesthetic, ethical and political intent. At the exhibition Bahia (Ibirapuera Park, 1959) designed in collaboration with Martim Gonçalves for the 5th São Paulo Art Biennial, Bo Bardi experimented with new resources such as the application and modelling of standard aluminium foil on a wall to exhibit a group of Baroque pieces, or the use of a whitewashed brick wall for a densely packed display of ex-votos. The choice of a metal structure with a concrete base for placing the artworks was equally worthy of note. This solution had previously been used by Bardi, but shells were added to the conical base in this exhibition. Bardi also erected two large trees made of paper flowers and weathervanes, creating an unmistakably festive impression. Embodying the idea of exhibition as an event, Bo Bardi covered the entire floor with eucalyptus leaves, evoking the terreiros de candomblé, and offered traditional food and dancing from Bahia at the opening ${ }^{30}$. In the exhibition Design in Brazil: History and Reality, held to mark the opening of Sesc Pompeia (1982), Bo Bardi sought to create an atmosphere of celebration and participation in equal measure ${ }^{31}$. She configured the show on two levels built with pine and construction scaffolding, and joined by a longitudinal ramp ${ }^{32}$, creating an architectural promenade through which each visitor might have different panoramic views over the dense nuclei of pieces arranged on pine supports or, in the case of furniture and machinery, directly on the floor. The pieces testify to Bo Bardi's anthropological reading of design, drawing as they do upon artefacts from indigenous cultures, pre-artisanal craftsmanship and Brazilian industrial production.

It was in 1968/1969 that Bo Bardi's architecture and museography really gained worldwide renown, with the opening of the new and monumental MASP headquarters on Avenida Paulista. For the new installation of Pinacoteca and the temporary exhibition A Mão do Povo Brasileiro, Bo Bardi executed the two display strategies that she had been working on since 1947: on one

28 Ibid, p.34.

29 Ferraz, Marcelo (ed.) Lina Bo Bardi. São Paulo: Instituto Lina Bo e Pietro Maria Bardi, 1993.

30 Latorraca, Giancarlo (ed.) Maneiras de Expor: Arquitetura Expositiva de Lina Bo Bardi. São Paulo: Museu da Casa Brasileira, 2014.

31 Lima, Zeumer. Lina Bo Bardi. New Haven and London: Yale University Press, 2013, p.92.

32 Latorraca, Giancarlo (ed.) Maneiras de Expor: Arquitetura Expositiva de Lina Bo Bardi. São Paulo: Museu da Casa Brasileira, 2014. 
side, standalone, translucent, portable plinths and bases were placed in an open space, allowing each visitor a wide field of vision; on the other side, a display system in raw or painted pine exhibited a large number of pieces evoking the cheerful and informal atmosphere of street markets and souks. Bo Bardi also established a close connection between the building (the container) and her exhibitions (the content) - one of the strengths of her museography. At the Pinacoteca, Bo Bardi used technical methods to refine the crystal easel (as she called it) for the placement of the individual painting. Buerge ${ }^{33}$ and Lima ${ }^{34}$ highlight the symbiosis between the suspended parallelepiped glass mass with a span of $70 \times 30$ metres, without pillars or divisions, and the easels with their cubic concrete base, a vertical plane of glass and wooden fasteners. The spatial experience offers each visitor a double sensation of suspension - the architectural structure into the city and the artworks into the space. Through the radical action of removing the captions from their conventional position, next to each work, and transposing them to the back of the canvas and the easel, Bo Bardi dissociated the act of seeing from the act of reading ${ }^{35}$, instead giving priority to the contemplation of each artwork ${ }^{36}$.

In contrast to the dematerialisation of the Pinacoteca space, the venue for the temporary exhibition was a closed, inside gallery that had no visual communication with the street. The exhibition $A$ Mão do Povo Brasileiro featured more than 2,000 popular objects, including ornaments, ex-votos and statues of saints, clothes, fabrics, furniture, tools, musical instruments, toys, faces and masks, all on panels and pine bases, some of them in steps, like "a regiment of handcrafted objects carefully organised, as if they could march straight out of the museum into the streets"'37.

Regardless of the theme and the place, Bo Bardi always conceived of the exhibition as an event, the manifestation of an aesthetic and ideological concept. Each installation was intended to be a public place for creation, education and socialisation, boosting social transformation. Bo Bardi sought to engage the public, guaranteeing them an initial perception of the space in its entirety, and encouraging each visitor to heed their peripheral vision. Eschewing the idea of a linear circuit and a closed chronological discourse, Bo Bardi held visitors responsible for finding their own meanings and discovering their own route through the pieces on display, which were positioned without any sense of hierarchy ${ }^{38}$.

33 Buergel, Roger M. "O local de nascimento da arte de instalação" in Pedrosa, A., Proença, L. (ed.) Concreto e Cristal: O acervo do MASP nos Cavaletes de Lina Bo Bardi. São Paulo: Cobogó e MASP, 2015.

34 Lima, Zeumer. Lina Bo Bardi. New Haven and London: Yale University Press, 2013, p.90.

35 Buergel, Roger M. "O local de nascimento da arte de instalação" in Pedrosa, A., Proença, L. (ed.) Concreto e Cristal: O acervo do MASP nos Cavaletes de Lina Bo Bardi. São Paulo: Cobogó e MASP, 2015.

36 Latorraca, Giancarlo (ed.) Maneiras de Expor: Arquitetura Expositiva de Lina Bo Bardi. São Paulo: Museu da Casa

Brasileira, 2014, p.26.

37 Lima, Zeumer. Lina Bo Bardi. New Haven and London: Yale University Press, 2013, p.90.

38 lbid. 


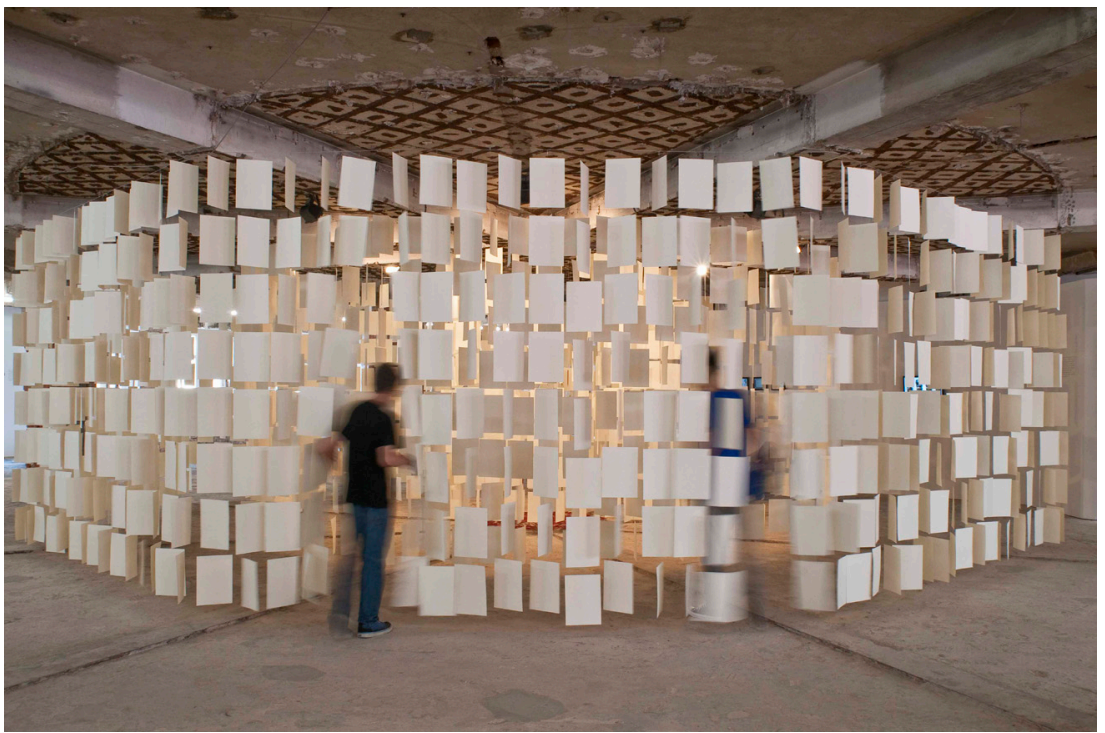




\section{Common ground}

Frederick Kiesler, Franco Albini and Lina Bo Bardi saw the exhibition as an experience triggered by visitors through their presence and participation. They activate the space as content without silencing the pieces or changing their meaning. The space is closely correlated with the artworks on display, and vice versa, in a symbiotic process that allows each visitor to have a memorable aesthetic experience that may take on an existential meaning. The three architects, assuming the role of curators, use only the specific language of an exhibition and remix conventional modes of communication and architectural vocabulary, exploring the natural and artificial light, materials, layouts, surfaces and geometries in innovative ways. All of them share a particular attentiveness and responsiveness to the perception and the experience of the visitor, encouraging each viewer to take different paths within the space. They openly placed importance on public participation, although they had different intentions in pursuing this objective. Kiesler, Albini and Bo Bardi may all be considered visionaries of our time, as they offer a landscape that stimulates our curiosity through a multiplicity of information arranged in a multisensory way, allowing each visitor to discover associations between himself and his surroundings. None of them simply created an opportunity for distraction or entertainment.

\section{Conclusion}

The strength of Frederick Kiesler, Franco Albini and LinaBo Bardiproposals to our contemporaneity lay in the fact that they designed exhibitions were, to quote Pallasmaa, "space, matter and time fuse into one singular dimension, into the basic substances of being, that penetrate our consciousness. We identify ourselves with this space, this place, this moment, and these dimensions become ingredients of our very existence" 39 . They considered the exhibition to be a work of art, overcoming the container/content dichotomy and trigging an intersubjective and self-reflective participation. This perspective is all the more pertinent nowadays, as the processes of digitalising information and virtualising the real may well lead to the dematerialisation of the physical experience of art. Their example may contribute toward the constant rethinking of the physical exhibition, considering the profound changes that have been occurring in global geopolitics and in all aspects of daily life, social habits, visual culture and the way we perceive the world - how we learn, communicate, move and relate to one another as a society. One of our present challenges is that the physical exhibition does not mimic other media or become mere entertainment that distracts and alienates. To this end, the exhibition must not contribute to the creation of a momentary, superficial look that consumes culture and arts like any other product. Instead, it must offer engaging and meaningful aesthetic experience through which people can transcend their own existence as individuals and as members of society. [Fig.4] 